\title{
Bringing the Multiplex to Antwerp: A Battle of Two Giants
}

\begin{abstract}
This article investigates the introduction of the first multiplex in Antwerp, Belgium. Within Europe, Belgium has traditionally been a leader in multiplex developments. Despite Antwerp's powerful position in terms of national film exhibition and distribution, the city's first multiplex arrived relatively late. By investigating the struggles of two major exhibitors in the late I980s and early I990s, this case of Antwerp connects to findings for other countries (particularly the UK and the US) concerning the effect of multiplexes on local exhibition structures and cinemagoing practices. In addition, it demonstrates how the specific time and location of the introduction of the city's first multiplex were dictated by the particularities of the local exhibition market, including its structure, its economic and political key players and its integration into the city's urban infrastructure.
\end{abstract}

KeYwords: multiplex; Antwerp; Belgium; film exhibition; cinema history

The shift in focus from the analysis of film texts to studying the contexts of film production, exhibition and consumption, an approach that would eventually be labelled New Cinema History, has resulted in a substantial body of case studies. ${ }^{\mathrm{I}}$ Compared to the first half of the twentieth century, there are few studies investigating more recent cinema histories and particularly the turn to multiscreen venues since the I980s in regions beyond the Anglo Saxon confines. ${ }^{2}$ As will be discussed in more detail in the next section, these studies suggest that the multiplex was partly a consequence and initiator of fundamental changes in all branches of the film industry in the last four decades of the twentieth century. They link the emergence of the multiplex to technological and social change, as well as to processes of suburbanisation and market concentration (with American chains in the lead), and ascribe to it an uplift of cinema attendance in the I980 and I990s. ${ }^{3}$ However, investigation is still required to ascertain if the emergence of the multiplex in other regions occurred along similar lines and which dynamics were at play. This is not only important given differences in size (geography and population), but also regarding cultural, economic and sociopolitical differences among European countries and regions. ${ }^{4}$

This article investigates the case of Antwerp, Belgium, with a focus on the introduction of the city's first multiplex and the struggles of two major exhibitors in the late I980s and early I990s - with each other as well as with local authorities. Within Europe, Belgium has long 
taken a pioneering position when it comes to multiplexes. Behind this success was the innovative exhibitor Albert Bert who, together with his sister-in-law, Rose Claeys, had been thriving on the success of his multiscreen formula since the late ig6os. They would gradually expand their empire and form what would become one of Europe's leading groups of exhibitors: the Kinepolis Group. Their multiplexes revitalised an otherwise dying classical film exhibition scene in various cities by providing up-to-date image and sound quality. This makes it even more surprising that, despite its immediate success in many Flemish cities, they did not open a multiplex in Antwerp, the country's second largest and second most important city for film exhibition and distribution, until I993, twelve years after the opening of Belgium's (and in fact Europe's) first multiplex: Decascoop in Ghent. As this article will show, one of the reasons for the delay was the powerful position of one exhibitor, Georges Heylen, who dominated Antwerp's cinema market from the I950s until the I990s. His powerful position within Antwerp's lucrative cinema market not only gained him favourable conditions when negotiating with representatives of Hollywood producers and distributors, but also in local politics.

The results presented in this study originate from two related historical research projects about film exhibition, film audiences and cinemagoing in Flanders. 5 For this article, methods and insights from social geography were combined with business history to gain a multilayered picture of practices of film exhibition and cinemagoing. Particular attention was given to the location, design, management and ownership of the cinemas and their integration into the fabric of urban life. ${ }^{6}$

By examining the workings of exhibition practices on a local level, this study shows that the case of Antwerp bears many similarities with findings from other case studies for the US and the UK. At the same time, it demonstrates the value of microhistorical research for a better understanding of the practices of film exhibition within their particular social, economic and media-historical contexts and the role of economic and political players in the local exhibition market.

\section{The impact of multiplexes on film exhibition and cinemagoing}

Literally, multiplex refers to a multiscreen cinema complex. However, definitions of the multiplex vary, particularly with regard to the minimum number of screens (ranging from two to eight), design (in- or exclusion of former single-screen cinemas) and ancillary activities.7 Following the generally accepted definition used by MEDIA Salles (co-founded by the European Union and representing experts from the industry as well as academia), in this article I distinguish between multiscreens on the one hand, and multiplexes and megaplexes on the other. In contrast to multiscreens, multiplexes and megaplexes have at least eight or sixteen screens, respectively, and were specifically designed for several screens. ${ }^{8}$

The first ideas of cinemas with two or more screens circulated as early as the I940s, yet it was not until the I96os that the multiscreen concept gained ground in the US and the UK.9 With multiscreen projection exhibitors aimed at maximising audiences while keeping costs low, 
as it allowed for higher economic efficiency (centralised business processes), fewer empty seats, more flexibility in film programming and potentially bigger choice for audiences. ${ }^{\text {IO }}$ As such, multiscreen projection was a reaction to an ongoing decline in cinema attendance which had been haunting the film industry since the immediate post-war years, a period characterised by waves of suburbanisation, increased mobility (cars) and changed leisure patterns. The changes in exhibition facilitated the switch in distribution practices from a downtown-orientated system of run zones to saturation booking, since multiscreen projection meant more screens in fewer sites and allowed for films to open more widely, but for shorter periods of time. These shifts also meant that exclusive screenings and premieres were no longer the privilege of downtown cinemas, but were increasingly scheduled for multiplexes located on the periphery of urban centres. ${ }^{\text {II }}$ This was propelled by the household invasion of cable TV and VCRs, which took over the role as second-run exhibition outlets in the I980s. This meant that it was not the film medium itself that had lost its appeal, but rather the practice of cinemagoing. ${ }^{22}$

Although the multiscreen concept initially seemed to halt the ongoing decline in theatrical exhibition, this was short-lived. The innovation in exhibition practices in the I96os and I970s did not result in the much-hoped-for revival in cinemagoing. Up until the late I970s, only ten percent of theatres were equipped with multiple screens, of which eighty percent had only two screens. ${ }^{\mathrm{I} 3}$ Particularly in the UK, admissions and the number of screens kept dropping, mostly at the cost of city-centre cinemas. The first-generation multiscreen cinemas were marked by several drawbacks, which were often the result of conversions of single-screen to multiscreen venues. The splitting up of formerly large auditoriums had its negative sides: tiny screens, poor sound (no soundproof auditoriums), obstructed sight lines and little comfort (leg space). ${ }^{\mathrm{I}}$

It took some drastic changes to successfully arrest the demise in the exhibition industry. A revived interest in the film medium spurred by the proliferation of VCR and cable TV, relaxed urban planning policies and, first and foremost, a changed notion of cinemagoing brought audiences back to the cinemas. Exhibitors realised that cinema was as much - or even more about the practice of cinemagoing as it was about the (choice of) films. As most multiplexes were integrated into large leisure complexes, cinemagoing could be marketed as part of a package of total entertainment, elevating it to an eventful night or even day out. ${ }^{\mathrm{I5}}$

Hence, the mid-I980s saw an immense proliferation of multiplexes with evermore and bigger screens, offering greater comfort and convenience, higher technological standards as well as easy access and ample and free parking. ${ }^{16}$ Moreover, a greater flexibility with regard to film programming lowered the risks of box office failures, which added to the advantages of lower operating costs for maintenance and staff due to centralised business processes. As they were often built on cheaper land on the peripheries of urban centres, the multiplex boom also had an impact on the (often traditional, non-multiplex) cinemas in downtown and city centre areas. Exactly how multiplexes affected existing cinemas, however, is difficult to assess, as it depends on a complex interaction of various factors, including the health of those cinemas, the local practices of cinemagoing and the local economic, cultural and traffic infrastructure. ${ }^{17}$ I will return to this discussion in the paragraphs below. 
In the wake of the success of the multiplexes, the mid-I990s saw a proliferation of a new kind of cinema: the megaplex. According to Charles Acland, the emergence of the multiplex was part of an industry-wide logic to "supersize" the cinemas, along with the concessions. ${ }^{\text {I8 }}$ Characterised by a large number of screens and large auditoriums, but most of all by a plethora of ancillary activities sold in addition to the film (such as game corners or live broadcasts of opera and sports events), cinemagoing had to become a lifestyle decision rather than a product-based decision. The horizontal integration of leisure activities had to bind costumers to the site for more than the duration of a film. ${ }^{19}$ Whereas early multiplexes were integrated into leisure complexes, in the megaplex, the cinema itself was 'the central, organising feature'. ${ }^{20}$ Often, the construction of megaplexes happened in the context of processes of 'recentralisation', or 'renewed interest in city centres, as both hubs of commercial activity [...] and of residential location. ${ }^{21}$ In order to revitalise degraded areas, cinemas, similarly to bars and restaurants, had to encourage customers to spend time in these areas outside normal shopping and working hours. ${ }^{22}$ However, the megaplex building craze was only a brief one, as the increase in the number of screens was not paralleled by increased attendances, thus rather 'eroding the industry's profitability'. ${ }^{23}$ Just like the multiscreen cinemas and multiplexes before them, the megaplexes turned out to be a temporary 'response to an ever-mutating set of conditions of screen traffic. ${ }^{24}$

Within Europe, Belgium was one of the forerunners in adopting the multiscreen concept. It was among the first countries in Europe to open a multiplex and the first country in the world to open a megaplex (see below). In I999, the country was among the top five European countries in terms of the number of multiplexes, and this despite its relatively small market (in terms of country size, population and admissions). ${ }^{25}$ Belgium's top position was grounded, to a great extent, in the success of what became known as the Kinepolis Group.

\section{The Kinepolisation of Belgium: the success of Albert Bert and Roos Claeys}

Before and after World War I, Belgium's cinema sector was booming. Even compared to nations with larger film industries in Continental Europe (such as France and Germany), Belgium had the highest number of cinemas per capita. ${ }^{26}$ The year 1957 saw the highest number of cinemas ever recorded in Belgium, with a total of I,585. At that point, however, Belgium's cinema sector was heavily oversaturated. After cinema attendance had reached an all-time peak in I945, it continuously declined until the I970s. Between I945 and I957 alone, the average number of tickets sold per cinema in Belgium had dropped by more than fifty percent. ${ }^{27}$

The success story of Kinepolis started in I970, when Albert Bert opened the first duplex in the Flemish town of Harelbeke, two years after he had taken over the cinema from his father and installed a second screen. After joining forces with his sister-in-law, Rose Claeys, in I972, they opened a triplex in Hasselt, followed by the five-screen cinema Pentascoop in Kortrijk in I975 (see Figure I for the animated history of the company posted at the corporate website). ${ }^{28}$ Although mostly operating separately, thriving on their multiscreen and multiplex success, Bert and Claeys would grow to become key players in the Belgian cinema market. 


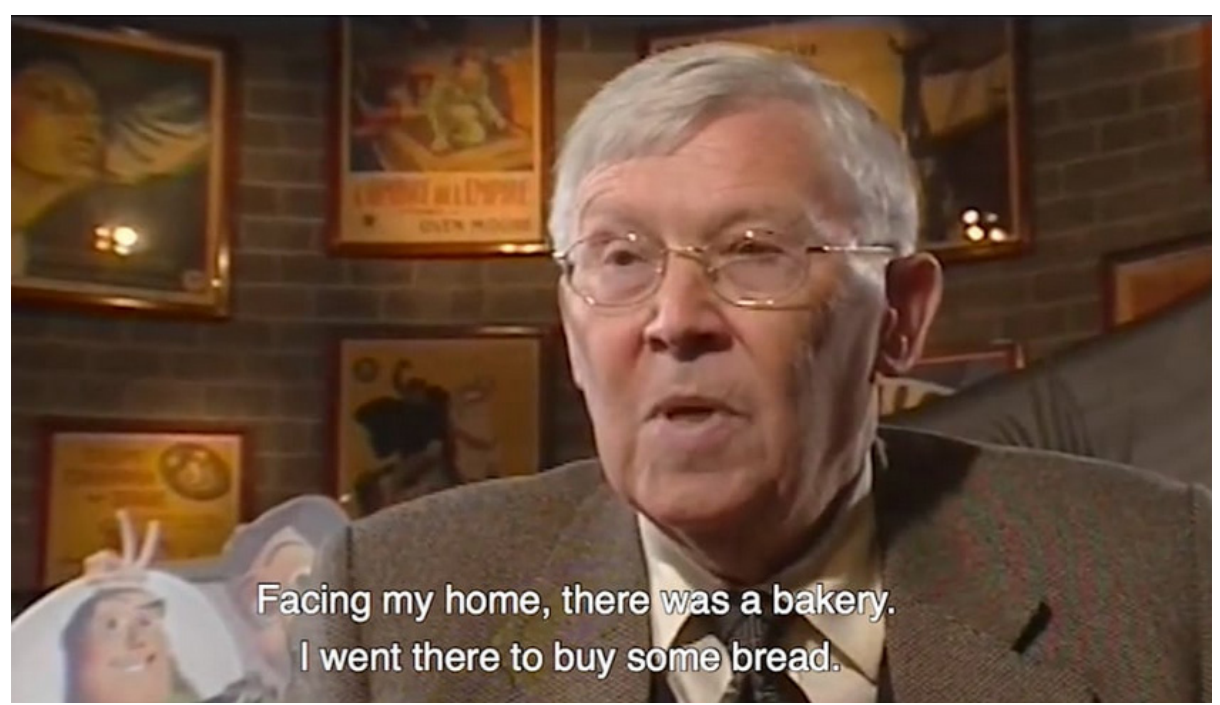

Figure 1. Kinepolis: Our History. Corporate film by Kinepolis about the company's history. Source: Kinepolis Group, accessed 30 November 2017, https://corporate.kinepolis.com/en/about-kinepolis/history.

After the opening of Decascoop in Ghent - the second largest city of Flanders after Antwerp and the capital of the province of East Flanders - in I98I, Bert and Claeys had increased their lead and solidified their position amongst the top Belgian exhibitors. Decascoop was the first purpose-built multiplex cinema in Europe and served as an inspiration for multiplex cinema architecture for representatives of the American majors. ${ }^{29}$ Seven years later, they would open the world's first megaplex, Kinepolis, in Brussels, housing twenty-five screens. ${ }^{\circ}$

For Bert and Claeys, the formula to success rested on three pillars: economisation of the business operation, quality and mobility of customers (meaning easy access and ample and free parking space). ${ }^{3 \mathrm{I}}$ The first pillar concerned management according to economics of scale. According to Bert, the economic advantages of the multiplex concept were the central projection booth, limited labour costs, the broad range of film supply, the possibility to screen a film on multiple screens without the need of extra copies as well as flexible programming depending on a film's performance. ${ }^{32}$

The second pillar - quality - was based on Bert's firm belief in the importance of permanent innovation in order to offer customers the highest comfort. As the group explained, based on an analysis and overview of cinema utilisation in Brussels, in agglomerations and nationwide, the cinema business was in fact about selling a "mix of product (film), presentation (projector and sound) and comfort (quick sale, friendly treatment and comfortable cinemas). 33 They realised that the cinema business was about the film-viewing and cinemagoing experience as much as it was about the film. Bert highlighted the disadvantages of the recycled multiscreens and the splitting up of theatres:

Often, this happened quite improvidently, with tiny auditoriums and little seating comfort. Twenty years later, nearly all metropolises have such outdated complexes with mini-halls, tiny screens and a vision and sound quality that is inferior to the hi-fi or video system in people's living rooms. And you don't even have the seating comfort as 
in the vintage cinemas from the forties and fifties, as they are only cherished in Antwerp any longer, and the restroom is the only place where you can stretch your legs. ${ }^{34}$

In other words, Bert and Claeys acknowledged that while they might have had less influence on the product, they could optimise the service. Hence, constant innovation was an important focal point and had to serve the enhancement of the film-viewing experience.

The Bert Group and Claeys Group predominantly invested in multiplexes located in urban centres and major regional centres. 35 Their efforts paid off and Belgium saw its cinema attendance rise once more. By the early I990s, Belgium had one of Europe's most technologically advanced cinema sectors. ${ }^{6}$ In 1997, the Bert and Claeys Groups were merged to form the Kinepolis Group, later simplified to Kinepolis, which would herald the beginning of almost a decade of international expansion. Currently, Kinepolis operates 499 screens in 48 cinema complexes in seven European countries, including the Netherlands, France, Spain, Luxemburg, Switzerland and Poland. 37

Remarkably, the Bert and Claeys Groups stayed away from Antwerp for more than two decades after Bert had opened his first duplex in Harelbeke. While they were successfully opening multiplexes in practically every corner of Belgium and abroad, it was only in I993 that they opened the megaplex Metropolis in north Antwerp, which was also the city's first multiplex. A major reason for this relatively late entry into Antwerp's lucrative exhibition market was its local structure.

\section{Antwerp Cinema City and the Rex cinema group of Georges Heylen}

As elsewhere in Belgium, in the medium-sized city of Antwerp, the number of cinemas kept growing until the late I950s (for a dynamic map of the location and capacity of the cinemas from I9O2 until 20I7, see Figure 2). At the end of World War II, Antwerp had 39 cinemas, and by the I950s the number had risen to $50.3^{8}$ Antwerp's exhibition market was highly fragmented, geographically as well as economically. In the immediate post-war period, cinemas were located in nearly every neighbourhood, with clustering of cinemas in a number of neighbourhoods and districts. Also, economically speaking, Antwerp's cinema market was quite fragmented until the Ig6os, with most exhibitors - or groups of exhibitors - operating one to three cinemas. In contrast to Ghent, for instance, where a third of the cinemas had to close down within a tenyear period, the number of cinemas in Antwerp remained quite stable until the early ig6os. 39

In terms of seating capacity, Antwerp's exhibition market was also quite heterogeneous, with cinemas varying from I5O to 2,000 seats. Most of the larger cinemas were located in the Station Quarter, yet this area also had a comparatively high number of small theatres. In other words, the diversity of cinemas, particularly in the Station Quarter, was quite impressive. The high concentration of screens and seats in Antwerp was mirrored by high admission figures, yet only initially. The average level of occupation of seats in cinemas within the agglomeration of Antwerp declined drastically within a decade; thus, while Antwerp's cinema market had a healthy appearance from the outside (in terms of the number of cinemas), it was already fragile on the inside (decreased attendance). 


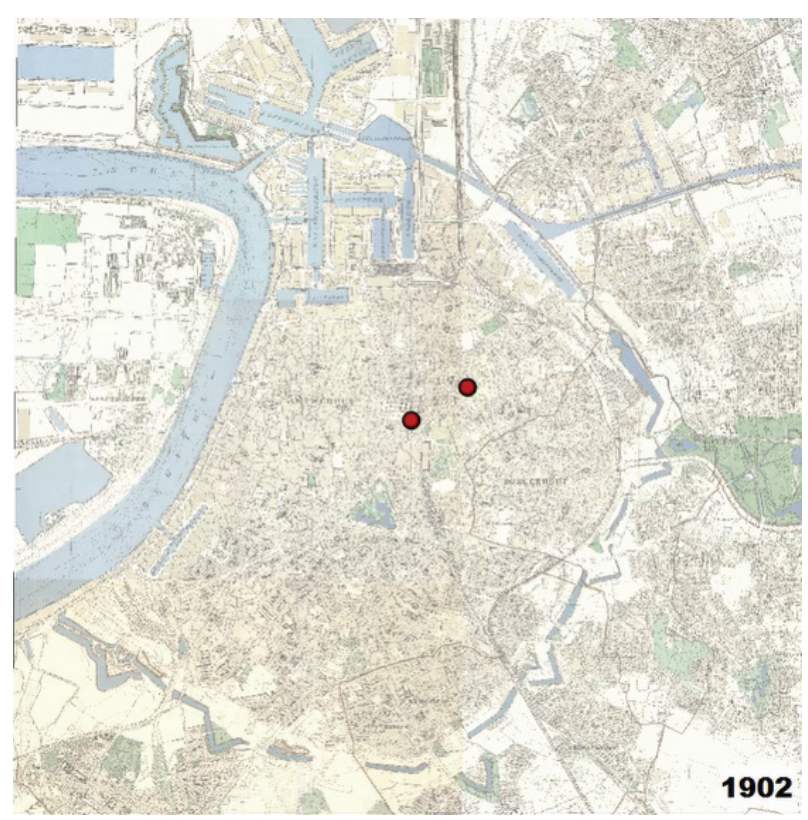

Figure 2. Dynamic map of the location of the cinemas in Antwerp and adjacent districts from 1902 until 2017 (see: https://vimeo.com/277556357/dade5ofd14). The different colours indicate the opening years of the cinemas. Red markers: cinemas opened before 1920. Orange markers: cinemas opened between 1920 and 1939. Yellow: between 1940 and 1959. Light green: between 1960 and 1979. Green: between 1980 and 1999. Blue: after 2000. The author wishes to thank Jaap Boter for helping creating this map.

The decline in admissions heralded the first radical break in the physiognomy of Antwerp's cinema landscape, and the I96os marked the beginning of processes of geographical and economic concentration. Similar to developments in the UK and the US, the golden era of the I950s in Flanders brought increased wealth and greater mobility, which affected recreational patterns (going on holiday, affordability of TV screens, etcetera). Yet, for many Antwerp citizens in particular, it also meant a massive abandoning of the poorer neighbourhoods in the inner city and the move to the outskirts, where modern apartment buildings offered more comfort and luxury. In addition, the large-scale introduction of television (after Belgium had hosted the first major World Fair Expo in 1958) meant that by the mid-I96os people would no longer find luxury and entertainment in cinema palaces alone, but were also given the alternative of watching entertainment programmes in their homes, which were now warm and cosy thanks to central heating. ${ }^{40}$ The neighbourhood cinemas were especially suffering the effects of this. In the course of the ig6os, the absolute number of cinemas in Antwerp dropped considerably - and it did so in most areas.

The maps in the dynamic map (Figure 2) above show a consistent clustering of a large number of cinemas in one particular area up until the I990s: the Station Quarter. This area accommodated not only the highest number of cinemas but also the most prestigious ones. It is the neighbourhood near Antwerp's Central Station and along both sides of the sumptuous avenue De Keyserlei - also referred to as 'Antwerp's Champs Elysées'. ${ }^{\mathrm{I}}$ The accumulation of between fifteen and twenty cinemas in the I950s within a radius of five hundred metres offered Antwerp's citizens and visitors film choices within one giant open-air 'multiplex' (see Figure 3). The wide 


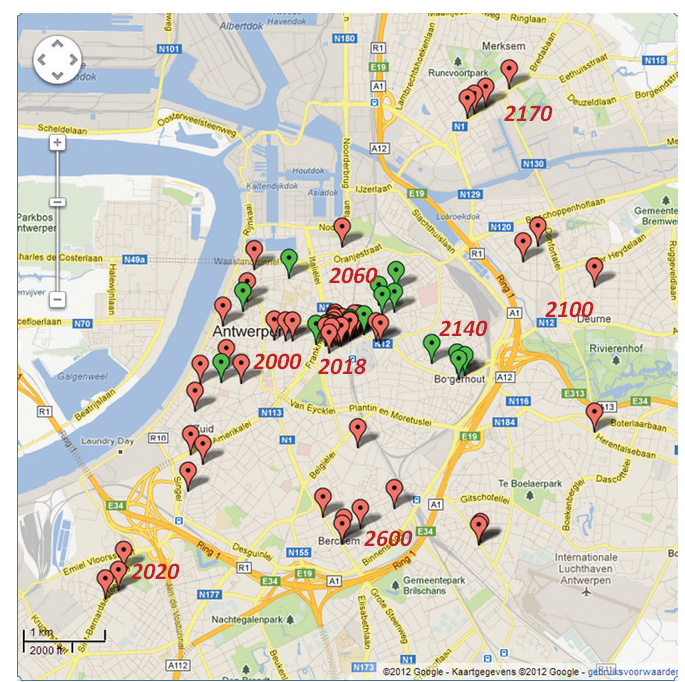

1952

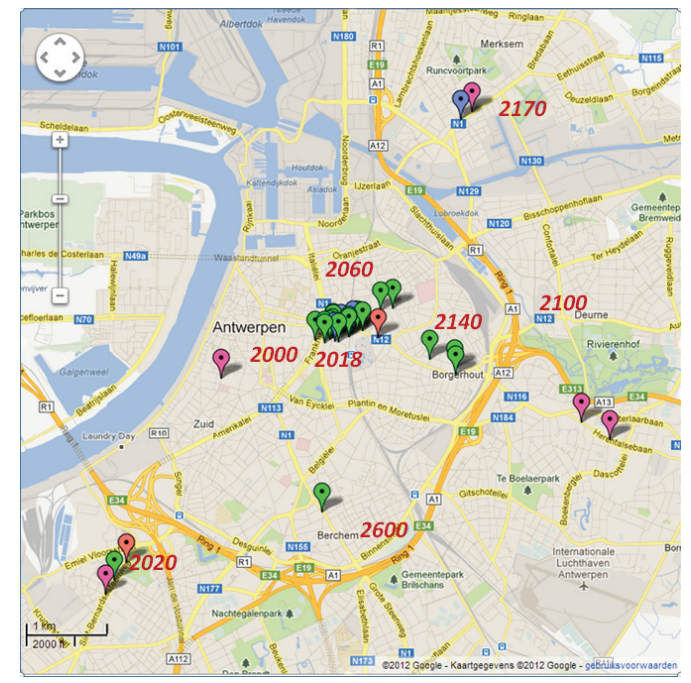

1972

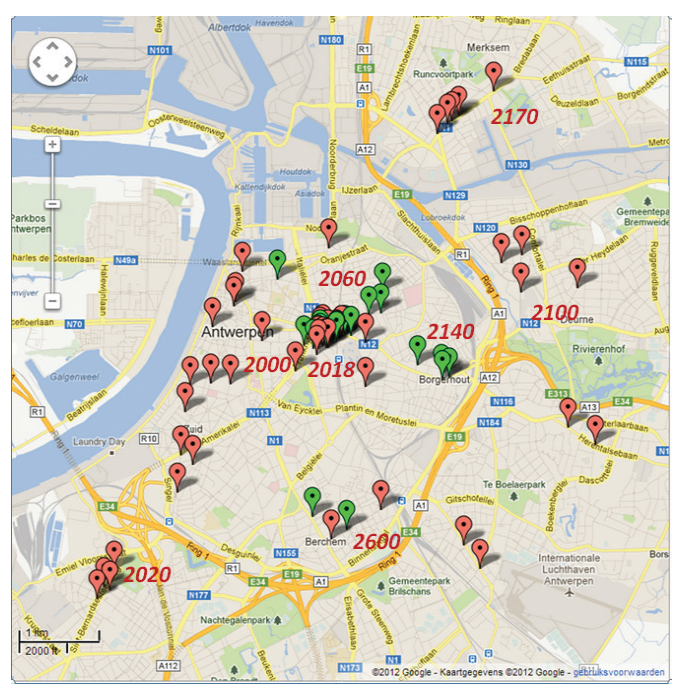

1962

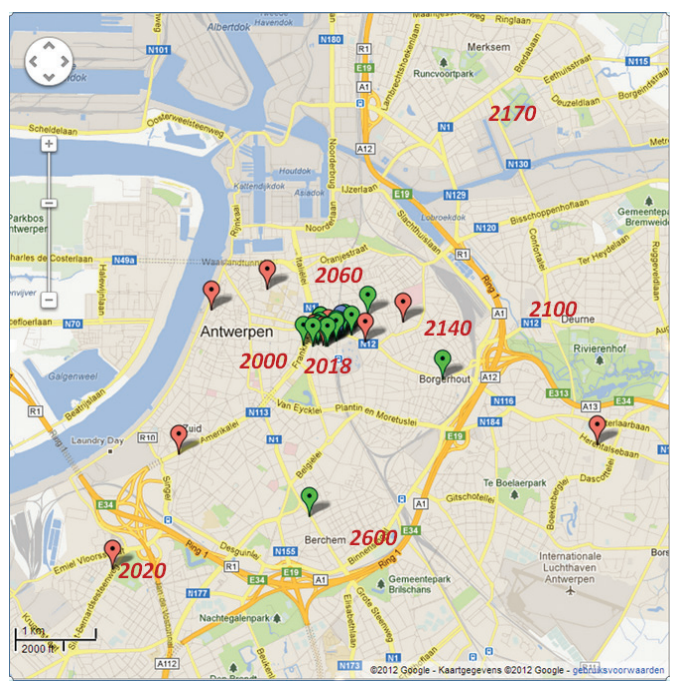

1982

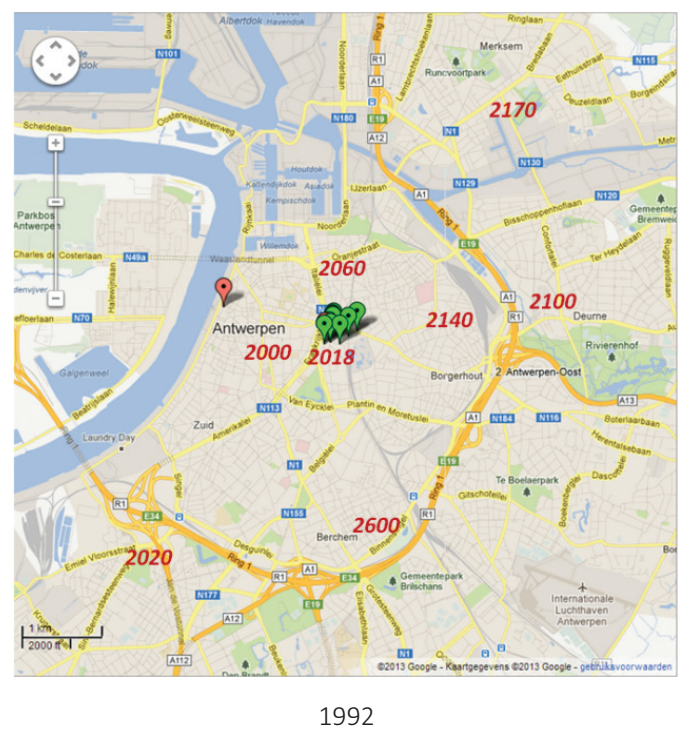

Figure 3. Map of cinemas within the Station Quarter in 1952, 1962, 1972, 1982 and 1992. The green markers depict cinemas belonging to Heylen's cinema group. Red markers: competing cinemas. Blue markers: exhibitors' names not documented. 
choice of films and cinemas in combination with easy access due to the favourable location near a broad range of public transport facilities gave the cinemas in the Station Quarter a great appeal. ${ }^{42}$

The Station Quarter was also the place where Georges Heylen (I9I2-I995) would start building his cinema empire after World War II. He became involved in the cinema business in the I930s, and in I94I he became the director of one of the most prestigious cinemas, the Rex, which was heavily damaged during World War II. After the reopening of the Rex in I947, Heylen would gradually take over one cinema after another until, by the late I96os, he gained a quasimonopoly position in the Station Quarter and had become the biggest exhibitor in Antwerp's inner city and adjacent districts (see Figure 3 for his growing power there). 43 Because of the prominent role of the Rex as Heylen's flagship cinema, his cinema group was often incorrectly - referred to as the 'Rex concern.'44

Along with the processes of geographical and economic concentration in the I96os, Antwerp's cinema landscape underwent yet another radical change in the I970s, with a gradual disappearance of the large single-screen and the opening of the first multiscreen cinemas. Midsize cinemas and big picture palaces no longer dominated Antwerp's cinema landscape, but rather small-size cinemas and screens. 45 The multiplication of screens also resulted in the number of screens in Antwerp's inner city and surrounding neighbourhoods and districts temporarily being higher (around I982) than in the early I970s, potentially increasing film offer and film choice.

Despite his leading position and his reputation for being original and innovative, Heylen was not the first to take the initiative in multiscreen exhibition in Antwerp. ${ }^{6}$ The first multiscreen to open its doors in Antwerp was Calypso (two, and later three, screens), opened in I973 by the successful Dutch cinema entrepreneur Piet Meerburg and located directly opposite Heylen's flagship cinema, the Rex.47 Calypso was soon followed by the film house Cartoon's (two, and later three, screens) in 1978 in Antwerp's historical centre. Yet, compared to most Flemish cities, in Antwerp, there was a lag in the number of screens relative to the number of seats..$^{8}$

Heylen only began following the multiscreen trend in I980, mostly by splitting up singlescreen cinemas or installing smaller screens in their basements. With the splitting up of his cinemas, Heylen also started 'redistributing' them across the Station Quarter: well-known cinema names disappeared only to surface again in other buildings (see Figure 4 as an example for the re-opening of cinema Odeon in I986). Most remarkable was the accumulation of four such multiscreen cinemas in the very same building complex situated on the corner of De Keyserlei and Anneessensstraat, which had been home to the Rex and the cinema Metro (Antwerp's largest cinema giant with more than I,500 seats) for more than four decades. 49 By accommodating four different cinemas practically under one roof, Heylen had actually created a thirteen-screen cinema complex. However, most of Heylen's 'new' auditoriums offered fewer than roo seats and were considered by cinemagoers as unattractive, tiny fleapits with little 'puppet' screens..$^{\circ}$ Heylen's ill management and half-hearted investments in more and smaller screens stood in contrast to the successful strategy of the Bert-Claeys family.

The splitting of single-screen cinemas and the reopening of multiscreen cinemas mainly occurred in the Station Quarter (and in Antwerp's historical centre), where cultural life was most lively. In contrast, cinemas in the districts closed down. They were predominantly owned 


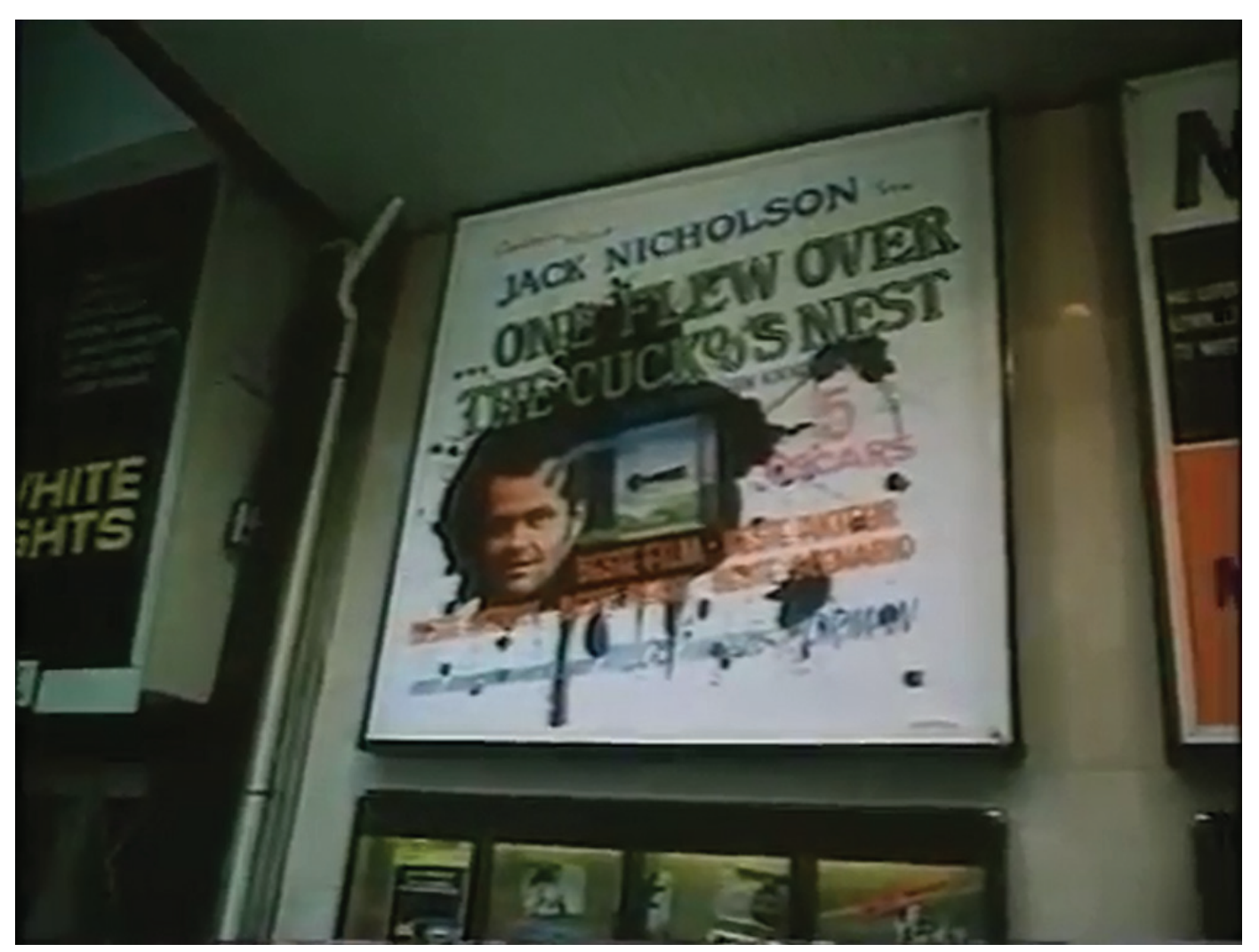

Figure 4. Edition of the newsreel Antwerpse Kinema Aktualiteiten about the relocation and re-opening of cinema Odeon as a multiscreen complex in 1986. Source: patsofilm, Cinema Odeon opening 1986 (online video, 23 April 2018). https://Youtu.be/iQYYs05Yxms. Approximately 1,500 of these newsreels were produced on behalf of Heylen between 1960 and 1992 to be screened at cinemas prior the main film. After his bankruptcy, a conflict about copyrights and preservation arose between the curator, co-producer Belgavox and Flemish television channel BRTN.

by private investors with a comparatively low number of cinemas. For them, the heavy investments were out of proportion to the potential earnings. The Station Quarter remained a magnet for cinemagoers up until the late I980s. For some, it was the last place in Belgium where cinemas still defined the streetscape. ${ }^{\text {II }}$ However, the previously mentioned depopulation of Antwerp's inner city went hand in hand with an increase of business there, including growing problems with traffic and parking. ${ }^{2}$ In addition, in the late I980s and the I990s, the Station Quarter - which had once been Antwerp's jewel in a literary and figurative sense - became increasingly associated with drug trafficking, high crime rates and dilapidated buildings. 53 These problems heavily affected cinema attendances and led to a cultural, social and economic erosion of parts of the inner city, especially the Station Quarter.

Although Heylen kept his relatively powerful position in terms of the number of cinemas, it was more or less a question of keeping up appearances. The neglected interiors of his remaining cinemas in the Station Quarter mirrored the poor situation on the streets outside. The closure of many of his cinemas along with the liquidation of many of his companies in the early I990 cast a looming shadow that indicated the fall of his empire. Ironically, I993, which became a top year for the Belgian cinema industry, signalled Heylen's ultimate downfall. 54 On 3 September I993, he was declared bankrupt and his remaining seventeen cinemas, most of which were located in the Station Quarter, had to close down immediately. About six weeks later, 
Metropolis, Antwerp's first multiplex (and megaplex), opened its doors in north Antwerp. The introduction of Metropolis, however, faced numerous obstacles.

\section{Bringing Metropolis to Antwerp}

By the end of the I970s, the cinema industry in six of the eight major cities and towns in Belgium was dominated by either Bert, Claeys or Heylen. Their territories were well defined, which suggests that they were not in direct competition. An analysis of the economic performance of cinema chains in Flanders in 1979 and I980 also revealed that, of the thirteen cinema complexes examined, Bert and Claeys' multiplex Pentascoop scored best, with Heylen's 'Rexconcern' [sic] second best. 55

As explained in the previous paragraph, Heylen entered the multiscreen business comparatively late. By the early ig8os, the differences between the exhibition strategies of the Bert and Claeys Groups on the one hand, and that of Heylen on the other, were striking: although Heylen operated more than twice as many cinemas in Flanders and Brussels in 1982 than Bert and Claeys put together, they had far more screens than Heylen at that point (see Figure 5). With Heylen having an average of I.4 screens per cinema, and Bert and Claeys, combined, having an average of 4.4 , they represented the opposite ends of the spectrum of the bigger players in the

\begin{tabular}{|c|c|c|c|c|}
\hline $\begin{array}{c}\text { Number of } \\
\text { screens }\end{array}$ & Heylen & $\begin{array}{c}\text { Bert }+ \\
\text { Claeys }\end{array}$ & $\begin{array}{c}\text { Other } \\
\text { exhibitors }\end{array}$ & $\begin{array}{c}\text { Total } \\
\text { Flanders + } \\
\text { Brussels }\end{array}$ \\
\hline I & I5 & 0 & I4I & I56 \\
\hline 2 & 2 & 2 & 25 & 29 \\
\hline 3 & I & 3 & I3 & I7 \\
\hline 4 & 0 & 0 & 4 & 4 \\
\hline 5 & I & 2 & I & 4 \\
\hline 7 & 0 & I & I & 2 \\
\hline 8 & 0 & 0 & 2 & 2 \\
\hline I0 & I & I & 0 & I \\
\hline $\begin{array}{c}\text { Total number of } \\
\text { screens }\end{array}$ & I9 & 9 & I87 & 2 II5 \\
\hline $\begin{array}{c}\text { Total number of } \\
\text { cinemas }\end{array}$ & 4.4 & I.5 & I.6 \\
\hline $\begin{array}{c}\text { Average number of } \\
\text { screens/cinema }\end{array}$ & I.4 & 40 & 274 & $34 \mathrm{I}$ \\
\hline
\end{tabular}

Figure 5. Total number of cinemas and screens in Flanders and Brussels in 1982 and the absolute shares of Heylen, and Bert and Claeys. Source: Federatie van Cinémas van België (FCB), "Lijst der 35 mm bioscopen 1982" (Brussels, 1982). 
exhibition market in Flanders and Brussels in the early I980s. ${ }^{6}$ In I987, one year before the opening of the megaplex Kinepolis, Bert and Claeys had also overtaken Heylen in terms of the number of venues: operating 3I cinemas in Belgium compared to Heylen's 29.

In addition to the differences in the venue-screen ratio, the two cinema giants also differed with regard to investment in innovation. As explained above, rather than choosing to substantially invest in long-term improvements, Heylen invested in superficial solutions to structural problems. This did not go unnoticed by outsiders. For example, Bert was quoted in the local newspaper regarding sharing his vision about exhibition, thereby also indirectly criticising Heylen as representative of the Antwerp market:

This one big cinema as a flagship surrounded by a lot of miniscule cinema halls is not Bert's idea of a modern cinema complex. 'Most often the difference in quality between the big and the smaller cinemas is too big. In Kinepolis, we don't scale down; sometimes there might be a hundred seats fewer, but every auditorium offers the same comfort, with double arm rests, space for the legs and a decent distance between the first row and the screen.'57

Next to Bert, members of the city council lamented the status of Heylen's cinemas, as will be addressed below.

A third reason for Heylen's relatively late arrival lies in a contract dating from I980 in which members of the Claeys family, on the one hand, and Heylen and F. Van Groeningen (director of the Rex group's distribution companies NV Excelsior and NV Filimpex at that moment), on the other, had stipulated several agreements. As part of the contract, Heylen agreed not to construct new cinemas or reopen existing ones in the Flemish province of Limburg, while the Claeys family were not to construct new cinemas or reopen existing ones in the provinces of Antwerp and West and East Flanders for a period of 20 years. In addition, Heylen had to guarantee the Claeys Group priority rights for his films in the province of Limburg for a period of ten years, while the Claeys, in turn, were obliged to screen his films there. ${ }^{8}$ Since the Bert side of the family was not included in the contract, there was no question of breach of contract when they opened Decascoop in Ghent in I98I.

The same agreements would hold for Antwerp, but it is alleged that Bert's plans for the construction of a multiplex in the city had already circulated by the mid-I980s. In I989, the year after the opening of Kinepolis in Brussels, the plans were picked up again. In a letter of August 1989, Albert Bert and his son, Joost, asked the local authorities for permission to construct a cinema complex in south Antwerp. The letter included details of the Berts' ambitious plans. The cinema complex would have twenty screens and six thousand seats and was not only supposed to become the 'most advanced and best conceptualised cinema of the world', but was to be accompanied by a 'big entertainment centre with a giant parking lot', later to be extended by 'a water park and sports facilities' (see Figure 6).59 The Berts concluded their descriptions of the entertainment centre by claiming that ' $[t]$ his village, which will already be a tourist attraction on its own, will be finalised with as much finesse as Main Street in Walt Disney Orlando'. ${ }^{\circ}$ 


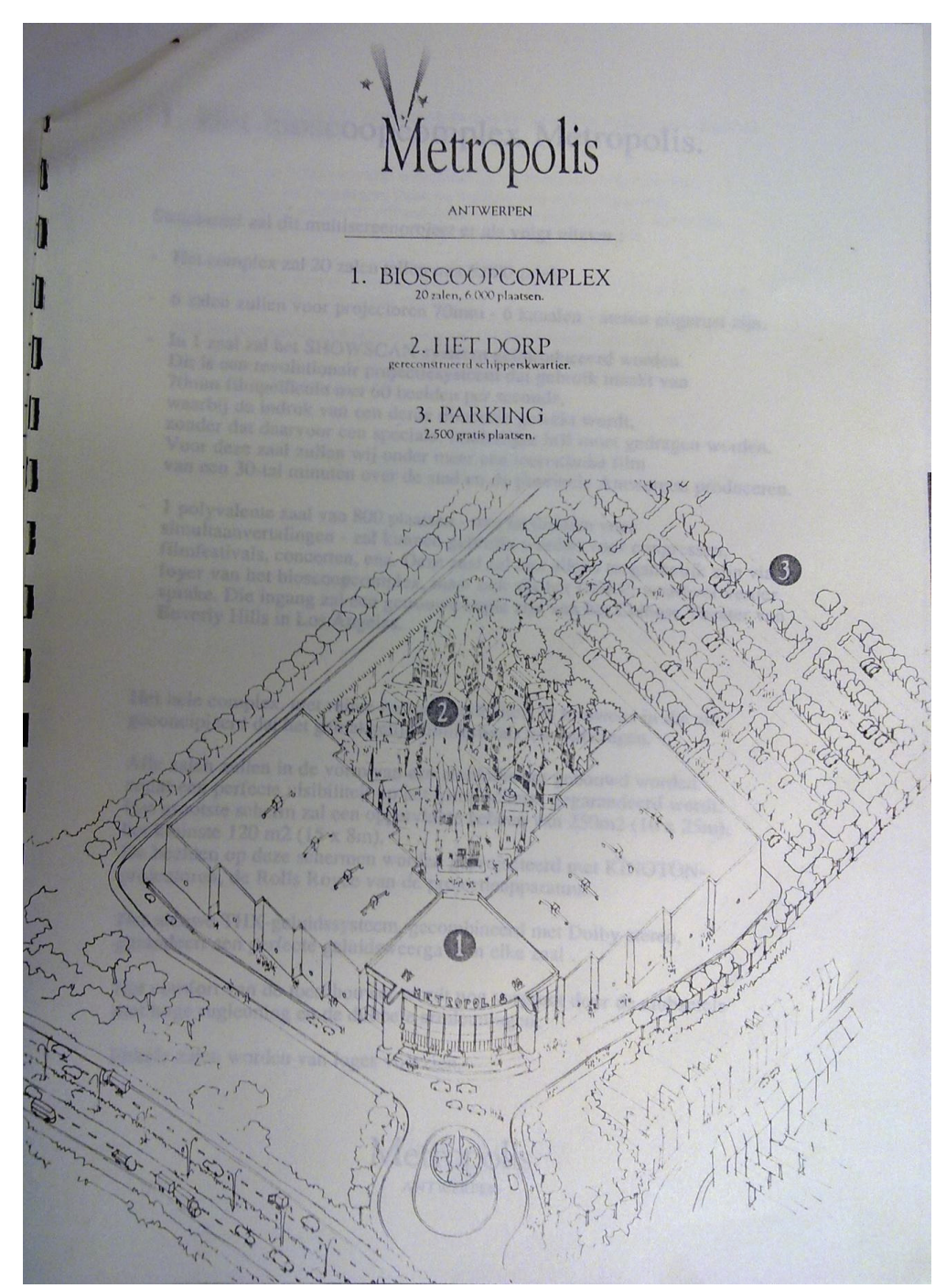

Figure 6. Sketch of the Metropolis complex as part of the dossier as submitted to the city of Antwerp in August 1993. The numbers indicate the corresponding parts of the complex: 1 - cinema complex, 2 - the village, 3 - parking.

Their plans clearly illustrate what Acland describes as a trend in the exhibition sector, where the Disneyland model was to serve as a positive example, with a variety of leisure activities combined in one location and the result that the cinema experience was only part of a package of 'total entertainment'. ${ }^{\text {II }}$ Implicit in this demand, as Acland suggests, is the message that it was not film that required refinement but rather 'the context of cinemagoing'. ${ }^{62}$ The Berts' design thus echoes what Acland discusses as the 'interconnectedness of media and contexts', which 'contributes to the fabric of everyday life as experienced and negotiated habitually by people. ${ }^{63}$ It also suggests that the Berts must have realised that - to use Hanson's words (pointing to the demise of the British cinema industry in the I970s and early I980S) - 'Film viewing as a popular cultural activity was very much alive: it was cinema-going that was not. ${ }^{64}$

Despite the grandeur of the project, the Berts did not gain permission from local authorities, primarily due to fears of possible threats for the inner-city cinemas, a possible gentrification of the area and an increase of traffic problems. At the same time, the city authorities were not entirely against such a project either and initiated a thorough and comprehensive 
investigation on behalf of the city of Antwerp considering the possibility of a cinema complex there. This investigation comprised two phases: first, an examination of the general interest in a new cinema complex in Antwerp and an estimation of the degree to which a new cinema complex would become a potential threat to the inner-city theatres; second, an examination of concrete locations. ${ }^{65}$

Such questions about possible installations of cinema complexes within cityscapes were not uncommon. In one of their first preliminary reports regarding more general considerations of the desirability of a multiplex in Antwerp, as well as of possible locations, members of the non-profit organisation Stad aan de Stroom (SaS, meaning City on the River) pointed to rescue plans for centre cinemas in Belgium as well as abroad. The members acknowledged the importance of the cinemas for the inner city by asserting that the

disappearance of the centre cinemas disturbs the functioning of the inner city. The centre cinemas represent a welcome counterweight for the concentration of offices and shops. The complementarity lies predominantly in the moment they generate activity and bustle. ${ }^{66}$

In addition, they underlined that ' $\mathrm{t}$ ] he conflux of cinemagoers and their influence on the surrounding catering establishments prevent the centre from looking dead and void after office hours. ${ }^{67}$ However, the team also recognised that

none of Antwerp centre cinemas [has] an architectural quality that is comparable to those in Brussels or abroad which had been included in the 'rescue program'. In addition, the interiors were just as irrelevant. ${ }^{68}$

By no means did the members of the SaS want to follow Brussels' model of subsidising threatened centre cinemas since it had actually failed its mission.

Taking the arrival of Kinepolis in Brussels as an example of how not to proceed, they formulated three pillars of a preventative policy for the situation in Antwerp. These included a considerable limitation on the programming of Metropolis, a protection of the function of the centre cinemas, and a stimulation of the modernisation of the cinemas. Ideally, Antwerp's cinema sector would be based on a bipolar model (as in the city of Liège), with, on the one hand, a cinema complex outside the city centre to recruit people from the region and, on the other hand, a healthy cinema life in the city centre predominantly targeting the city dweller. ${ }^{69}$ There were preconditions for a successful implementation. First, Heylen must commit himself to continuing the utilisation of the centre cinemas and investing in their modernisation. Second, it was required that the two poles - that is, Heylen and the Bert and Claeys Groups - would have to be equivalent. To ensure this, the centre cinemas had to remain under one umbrella to offer sufficient counterweight to the suburban cinema complex. Third, Antwerp's cultural sector had to guarantee that the arrival of Metropolis would not result in an impoverishment of the film supply. Fourth, a statement had to be made 
acknowledging that the disappearance of the cinemas in the city centre would lead to a further erosion of the city. ${ }^{\circ}$

The reports clearly demonstrate the general interest of the city in a new cinema complex, albeit under the condition that the continuance of the inner-city cinemas could be safeguarded. The latter was also in the interest of proprietors of the restaurants and shops in the Station Quarter, who feared that the closure of the cinemas would contribute to the degradation of the area. What was most astonishing, however, was that according to the results from a survey conducted by the local newspaper, the target group of the whole enterprise - Antwerp's citizens and the cinemagoers themselves - could not care less: there was a low response, and more than eighty percent of the respondents deemed a new cinema complex as not desirable. ${ }^{\mathrm{I}}$

A review of newspaper coverage indicates that the different parties in the city council remained split in their opinions on the issue. Members of the city council belonging to the Christian People's Party (CVP, of which Heylen was also a prominent member) and the green party Agalev (abbreviation for 'Anders Gaan Leven', meaning 'living differently'), for example, argued against the introduction of Metropolis, as it would threaten the cinema business as well as cultural and economic life in the Station Quarter. Antwerp's mayor, Bob Cools, remarked that it 'would be a shame if a cinema such as the Rex would disappear, for such a symbol should remain in existence, if only for historical reasons. ${ }^{72}$ In contrast, councillor for city planning and member of the Socialist Party (SP), John Mangelschots, argued in favour of Metropolis by pointing to the poor situation of the cinema sector in the Station Quarter, suggesting that the question depended on the way in which the inner-city cinemas were utilised in the future. Mangelschots also pointed out that although several ideas had been put forward, with the exception of Metropolis, no other plans had yet been substantiated with details or building applications. ${ }^{73}$

Mangelschots' concerns mirrored arguments brought forward by the PR manager of the Bert and Claeys Groups, Christian Nolens, who resolutely rejected arguments against Metropolis by emphasising that instead of trying to steal cinemagoers from the centre cinemas, the group aimed at revitalising cinemagoing in Belgium by bringing other segments of the population back to the cinemas - those who rarely, if at all, visited cinemas. Metropolis was presented by the cinema group 'as a kind of universal "Authentic Antwaarps Cinema", but then the biggest and the best.' 74 In addition, as Nolens argued, cinema attendance in Antwerp had been declining dramatically for twenty years, and six percent of the audience in the multiplex Kinepolis Brussels actually came from Antwerp city.75

The decision for or against the construction of a multiplex in the suburbs of Antwerp was the first and also the last great battle of two giants in Antwerp's cinema sector during the whole period of the Rex cinema group's existence. By I990, the Bert and Claeys Groups had 7I screens in Belgium, while Heylen had 28. The local press extensively covered the race for Antwerp's first multiplex, and as often as there were items about Metropolis, there were comments against it by Heylen. His manifold arguments usually centred around two issues: that Antwerp's citizens would never go and see a film somewhere outside of the city when they could combine cinemagoing with a good night out in the centre, and that Metropolis would remain a utopia. 


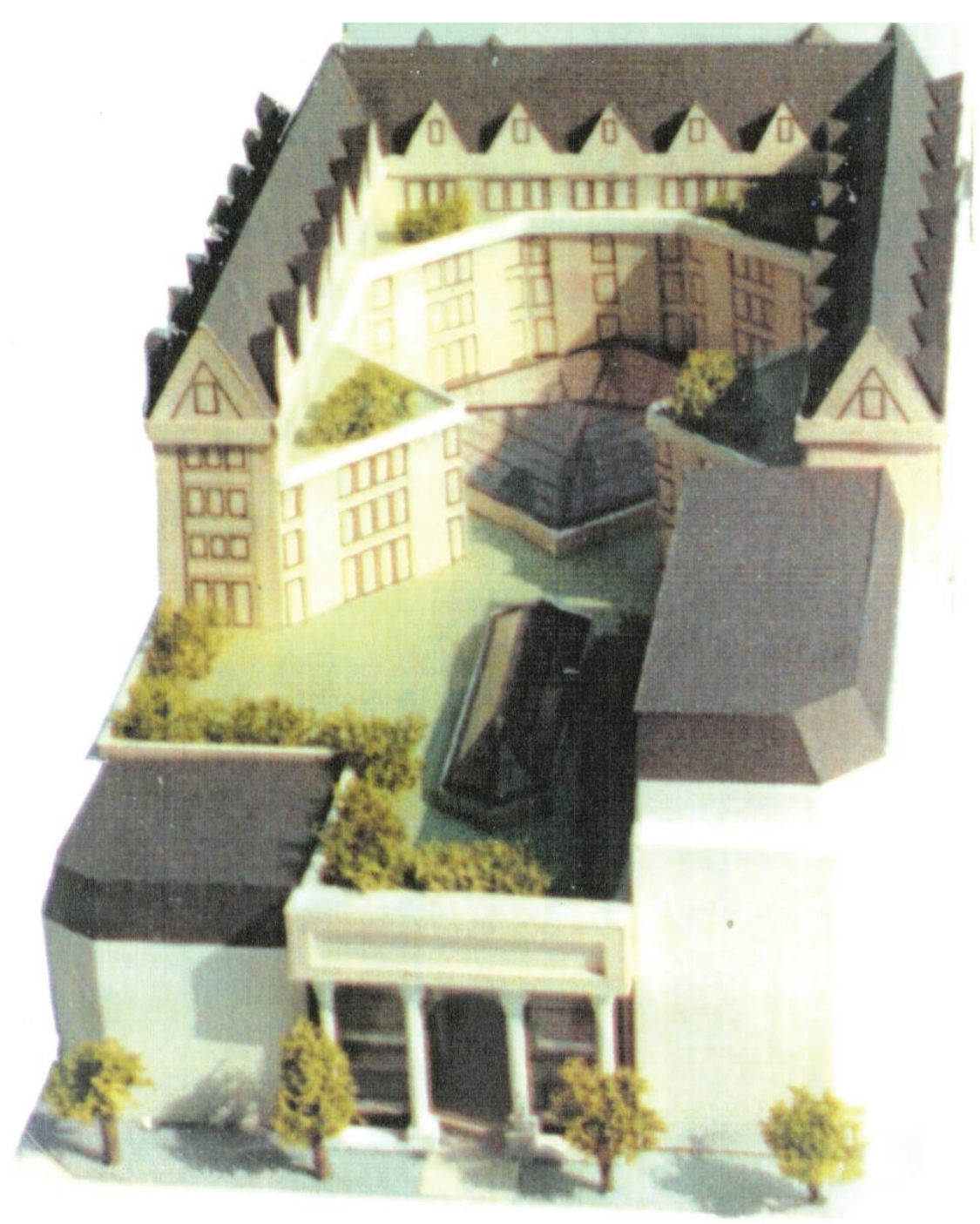

Figure 7. Picture of the maquette as part of the plans for a multiplex in the building complex looked at from the De Keyserlei - Anneessenstraat. Source: Brochure by French architect Sylvia Denicelle, kept in the archive of insolvency records of the Rex group.

When this utopia gradually became reality and the construction of the megaplex in north Antwerp was as good as certain, Heylen countered NV Metropolis' intentions by publicly announcing his plans for a new Rex complex in the beginning of January I993. The idea was to transform the building complex that housed the cinemas Rex, Metro and two other multiscreen complexes (see above) into one 'multiplex', with fifteen screens and at least five thousand seats. The plans included a private parking garage, as well as business and living space. ${ }^{76}$

Eric Kloeck, co-founder of Antwerp's second multiscreen cinema, who had become Heylen's sole competitor in Antwerp's inner city by the early i990s, expressed his doubts about Heylen's plans. He pointed to the recent waves of closures under Heylen as well as the dilapidated condition of the Station Quarter as the main causes of the declining cinema business there. He also did not believe in what was repeatedly brought forward by Heylen as one of the quarter's best assets compared to the future location of Metropolis outside of town: the cinemas' integration 
with the city's mass public transport system. According to Kloeck, at that time, public transport was in a state too lamentable to be truly reliable.77

Heylen, who had once built his career by being innovative and original, increasingly showed signs of complacency and neglectful behaviour. When asked why he would not invest in new multiplexes, Heylen replied that he would only have to build a roof on top of the De Keyserlei and he would have the biggest multiplex in the world..$^{8}$ Heylen's mismanagement was commented on by many insiders as well as outsiders of his cinema group and would later be succinctly highlighted by Metropolis' lawyer, Jan Theunis, who claimed that because of the mistakes of Heylen and others involved in the Rex cinema group, mistakes

which were sufficiently known within public opinion (and, amongst others, a total lack of policies regarding film programming, personnel and investments, whereby the cinemas perished from a non-existing seating comfort and an absolute lack of visual and auditive quality), the aspect of Antwerp's cultural life which film could have become was completely ruined.79

Gradually, Heylen had to close one cinema after another and sell the buildings. In public, he suggested that the transactions were merely a way of saving money for the construction of a new cinema complex at the heart of Antwerp. In reality, however, the wave of closures that had haunted most of his competitors during the previous decades was now starting to catch up with him.

In April I993, building permission for the megaplex Metropolis, six kilometres north of the Station Quarter, was granted by the city council, and one month later, the Bert and Claeys Groups founded its corresponding company, NV Metropolis. Among the most important criteria for their choice of location were accessibility, low property prices, and available space. Also relevant for the admission of the building permit was the benefit of Metropolis for the project Punt-aan-de-Lijn ('Point at the Line'), the most northern depot for Antwerp's public transport system (called De Lijn, 'The Line'). This project was targeted at the complementary use of the parking garage by commuter traffic during the day, while Metropolis was to provide streams of travellers in the evenings. ${ }^{80}$

At the beginning of August 1993, when it became clear that Metropolis' arrival could no longer be stopped, Heylen resorted to the I980 agreement (see above) and had NV Metropolis summoned. He claimed a sum of 500,000,000 BEF (approximately €I3,250,000) in damages compensation, because NV Metropolis had breached their agreement. This judicial conflict would eventually outlast Heylen's cinema enterprise, which would be declared bankrupt one month later. The dispute would eventually be settled in an amicable agreement in which Metropolis was to pay Heylen and the curator of his now bankrupt business the far smaller sum of I,500,000 BEF (approximately €40,000). ${ }^{8 \mathrm{I}}$

On 3 September 1993, Heylen's cinema group was declared bankrupt and all cinemas had to close immediately. For him, the Station Quarter had been the place where it all began and where it all ended. After his bankruptcy, of the nineteen cinemas in the Station Quarter that 
were open forty years earlier, only two multiscreens were left, both operated by Kloeck. In contrast to Heylen, Kloeck seemed to welcome the arrival of Metropolis. His open attitude towards some kind of low-key collaboration in order to make cinemagoing attractive again was shared by representatives of Metropolis NV, who also underlined the benefits for the inner city. ${ }^{82}$

On October 17, 1993, six weeks after Heylen's downfall, Metropolis opened its doors. It started with ten screens on the opening day and was quickly extended by an additional fourteen screens, offering nearly nine thousand seats. For the agglomeration of Antwerp, the opening of Metropolis made up for Heylen's bankruptcy, at least in terms of screens: five cinemas with a total of twelve screens were replaced by a twenty-four-screen megaplex.

\section{The aftermath}

A survey of two hundred visitors to Metropolis in 1995-1996 showed that approximately half had travelled more than twenty kilometres, mostly coming from Antwerp province or even from the Netherlands. In other words, the results implied that it was not necessarily inner-city folks that were attracted by Metropolis, but predominantly people from outside (the distance between Metropolis and the Station Quarter is about four kilometres). When asked about the advantages of watching a film in Metropolis as opposed to the Station Quarter, nearly half of the respondents praised easy access, and a quarter appreciated the on-site parking. ${ }^{83}$ The film offering scored relatively low (seven percent). In contrast, three major advantages of the inner-city cinemas were the opportunities of having a good night out (by combining cinemas and restaurants), proximity, and public transport. ${ }^{84}$ On the one hand, the outcome of the survey showed that Heylen had highly underestimated the power of Metropolis in attracting visitors from far beyond the multiplex's location. On the other hand, it also confirmed what he had repeatedly emphasised: Antwerp residents appreciate the relaxing cosiness of the Station Quarter, where they can enjoy a post-film beer in one of the countless bars or cafés at or near De Keyserlei. ${ }^{85}$

The city council, as one of Heylen's biggest creditors, had been split regarding the question of whether or not to collect the debts (and have Heylen go bankrupt). They realised that with the closing down of a still quite remarkable number of cinemas, the quarter's gastronomical and cultural scene would suffer dramatic losses. The prime motivation of their thorough and in-depth investigation of the consequences of the construction of a new cinema complex in Antwerp was always to ensure the perseveration of the inner-city cinemas. In I985, Heylen was quoted in the financial economic magazine Trends as saying: 'If I would switch out the lights in my cinemas, Antwerp dies. I live on the food industry, the food industry lives on me. ${ }^{86}$ His prognoses as well as the concerns of the city council about the quality of cultural life in the Station Quarter turned out to be justified.

An analysis of the causes and effects of the shifts in the location of cinema businesses in Antwerp (after the coming of Metropolis) showed that before I993 the Station Quarter was a multifunctional cultural and nightlife quarter in which the high concentration of cinemas played a vital role. After Heylen's bankruptcy, however, the process of cultural and economic erosion that had been haunting the Station Quarter since the I980s deepened even further. In 
particular, restaurants suffered from the massive closure of cinemas there. Restaurant owners and catering managers reported a loss in sales of up to seventy percent. ${ }^{87}$ Other restaurant owners with businesses located at De Keyserlei who were interviewed for the national newspaper De Standaard spoke of between thirty and forty percent losses. ${ }^{88}$ In addition to such loss of earnings, the closed cinemas left ugly architectural scars in the Station Quarter, increasing its dilapidated appearance and rendering it even more of a no-go area for inhabitants and visitors alike. In the words of Kloeck, 'Antwerp's Station Quarter has become a cinema graveyard which is in the process of being annexed by the Bronx. ${ }^{89}$

Ilse Laureyssen and Myriam Jansen-Verbeke's study of the causes and effects of the shifts in the location of cinema businesses in Antwerp underlined the necessity of strong involvement of the local authorities and concluded that a slowing down of the decline of the inner city, and its eventual revitalisation, had to be based on elaborate policymaking and well-thought-out plans. $9^{\circ}$ A report by the estate agent responsible for the sale of the building complex that housed Heylen's last Rex cinemas exposes the difficulties of this enterprise, such as urban planning restrictions concerning parking space and architectural changes of inner-city buildings. While the city councillor for urban planning, Mangelschots, was initially quite reserved about the preservation of the inner-city cinemas in the times of Heylen's reign, he was now very positive about, and even encouraged, the plans of a new multiplex in the Station Quarter and eased some of the restrictions. ${ }^{9 \mathrm{I}}$ At the beginning of 1995 , a group of investors made a bid, in a sealed envelope, of 335,200,000 BEF (approximately €9 million) for the building complex..$^{92}$ Apart from a multiplex, the reconstructed building was to accommodate a parking garage and ample shopping and gastronomic space and would be presented to the public under the name 'Rex Center' as homage to the cinema palace that had been there for more than half a century. Among those interested in utilising the new cinema complex were two international cinema chains (MGM and Gaumont), both of which had previously figured in Antwerp's cinema history on this very spot. Eventually, Gaumont was the one to proceed. The demolition work of the building complex started in the last months of I995, about the time that Heylen passed away. In I997, Gaumont opened a seventeen-screen multiplex with a total of 3,650 seats right on the spot where Heylen had dreamt of opening his fifteen-screen multiplex half a decade before. 93

\section{Conclusion}

The analysis of the Metropolis case allows for specific insights into changes in film exhibition on a local level, while also making clear a number of issues on a more general level. The case of Antwerp bears similarities with, and underlines conclusions based on, other case studies, yet also helps in nuancing these and other conclusions.

Similar to the US and UK, the proliferation of multiplexes in Belgium effected a radical change in exhibition structure and succeeded in getting cinemagoers back to watch more films outside of their homes. In Belgium, the success of the Bert and Claeys Groups proved that people had not completely unlearned the habit of cinemagoing. Bert and Claeys were 
frontrunners with regard to multi- and megaplex building, by ceaselessly investing in new ideas and concepts and anticipating changes in urban and media landscapes. Heylen, on the other hand, chose to invest in installing basement cinemas or in splitting up and recycling former picture palaces, rather than investing in new cinema complexes with bigger screens (not necessarily larger auditoriums). Heylen's ways of boosting box-office results were mostly short-sighted measures. Instead of attacking the problem at its roots and enticing cinemagoers back through real improvements (keeping up with the latest technical standards and offering optimal seating and viewing comfort and easy access), he kept his dwindling empire alive by patching it up and treating symptoms instead of causes. It is here that the situation of Heylen's cinema group and the state of his inner-city cinemas echoes what Hanson described for the British cinema sector in the I970s and early I980s as being too lamentable to enduringly boost attendances, as short-term solutions were implemented for structural problems. Just as the British exhibition market only regenerated after a boost from outside (the American Multi-Cinema chain), it took an outsider and investments in a megaplex to make cinemagoing in Antwerp attractive again.

As to the discussion of cinemas' role in revitalising degraded areas, this case study showed that this was also explicitly put on the agenda of local authorities. Similar to what has been observed by scholars for cities and towns in the UK, in Antwerp, local authorities were aware of the importance of the cinemas for the viability and vitality of the Station Quarter. Here, most of the inner-city cinemas did close on the eve of the opening of Metropolis. However, they did so for a number of reasons, and it was not a one-way causality or simply the result of top-down forces. Rather, the closure of most of the inner-city theatres and the arrival of the megaplex in north Antwerp in the early I990s were as much the product of interactions between representatives of the market and urban planners as they were dictated by the condition of the inner-city cinemas and the demand of the local population.

The question was not if a multiplex would open in Antwerp, but when and where. The specific time and location were very much dictated by the particularities of the local market: the poor state of the Station Quarter, which gave a multiplex situated outside the city centre the notion of a safe haven; the poor maintenance and management of the inner-city theatres; Heylen's powerful position on the local market thanks to his long-time experience as an exhibitor and distributor, vis-à-vis an equally powerful group of exhibitors from outside who were desperate to be finally getting the opportunity to bridge the gap to Antwerp's lucrative market; and the deep split within the local authorities between those in support of Heylen and those against him. The case of Antwerp thus also supports arguments against the centre periphery dichotomy by illuminating the workings of exhibition practice on a local level, where centre and periphery strongly interact.

Along this line, the case of Antwerp also feeds into the broader discussion regarding claims that the multiplex killed existing inner-city cinemas. Scholars have shown that, for a number of cinema businesses in the UK, non-multiplex cinemas with a multiplex in the vicinity can actually thrive, under the condition that they offer a comparable service. However, this would require serious refurbishment for existing cinemas. As local authorities and exhibitors in Antwerp stressed, and what has also been concluded from case studies in the US and UK, the 
opening of a multiplex does not necessarily have to pose a threat to inner-city cinemas, as it can build new audiences instead of withdrawing them - provided, however, that a number of factors are safeguarded: easy access (which in the city centre is more likely to be public transport), other leisure facilities such as shops and restaurants, good choice of films, proper maintenance of the sites and a high level of comfort for the viewing experience. The case of Antwerp thus also supports arguments against substitution hypotheses, showing that new exhibition outlets (VCR, cable TV, etcetera) did not necessarily replace older ones (theatres). Films themselves had not lost their appeal, but cinemagoing had, at least in the form it had functioned in the heyday of cinema.

Finally, on a methodological level, this chapter has again illustrated the worth of microhistories. As well as being able to put similar case studies of successful cinema entrepreneurs together in an attempt to understand, compare and contextualise findings, the value of microhistories also consists of their ability to point to possible collisions with existing histories on a meso- or macroscale, such as observations of the dominance of US chains blanketing Europe with multiplexes. Obviously, this did not apply to Belgium, where Heylen and the Bert and Claeys Groups knew how to optimally serve the market and divide it amongst themselves in times when they were still two of the most important players in the national market. Microhistories thus expose the workings of exhibition (and distribution) practices on a local level, thereby contributing to our understanding of transnational interactions and flows related to circulation and consumption of films.

\section{Notes}

I. A selection of recent work has been published in edited volumes, including R. Maltby, D. Biltereyst and P. Meers, ed., Explorations in New Cinema History: Approaches and Case Studies (Malden/Oxford, Wiley-Blackwell, 20II); D. Biltereyst, R. Maltby and P. Meers, ed., Cinema, Audiences and Modernity. New Perspectives on European Cinema History (Oxon/New York: Routledge, 2012); K. Aveyard and A. Moran, ed. Watching Films. New Perspectives on Movie-Going, Exhibition and Reception (Chicago: Intellect, 2013); R. Maltby, D. Biltereyst and P. Meers, ed., Routledge Companion to New Cinema History, (London \& New York: Routledge, forthcoming 2018).

2. K. Aveyard and A. Moran. "Introduction: New Perspectives on Movie-Going, Exhibition and Reception," in Watching Films. New Perspectives on Movie-Going, Exhibition and Reception, ed. K. Aveyard and A. Moran (Bristol \& Chicago: Intellect, 20I3), 6. Exceptions are, for example, A. Athique and D. Hill, The Multiplex in India: A Cultural Economy of Urban Leisure (London and New York: Routledge, 20I0); I. Vandevelde, "Moving Indians, Indian Movies. Hindi Film Structures and Indian Audiences at the Crossroads in Antwerp” (PhD thesis, University of Antwerp, 20I2); L. Van de Vijver, "The Cinema Is Dead, Long Live the Cinema!: Understanding the Social Experience of CinemaGoing Today," Participations. Journal of Audience \& Reception Studies I4, no. I (20I7): 129-44.

3. See, for example, D. Gomery, Shared Pleasures. A History of Movie Presentation in the United States (Madison: University of Wisconsin Press, I992); C. R. Acland, Screen Traffic. Movies, Multiplexes, and Global Culture (Durham/London: Duke University Press, 2003); M. Jancovich and L. Faire with S. Stubbings, The Place of the Audience (London: BFI, 2003); S. Hanson, From Silent Screen to Multi-Screen. A History of Cinema Exhibition in Britain since 1896 (Manchester: Manchester University Press, 2007).

4. Judith Thissen, for example, justifies the need for comparative cinema history for European countries and regions, arguing that, compared to North America, film culture there was less regulated and homogenised. J. Thissen, "Introduction: A New Approach to European Cinema History," in Cinema Beyond the City: Small-Town Q Rural Film Culture in Europe, ed. J. Thissen and C. Zimmermann (London: BFI-Palgrave, 20I6), I-22, 3.

5. “'The Enlightened City': Screen Culture between Ideology, Economics and Experience. A Study of the Social Role of Film Exhibition and Film Consumption in Flanders (1895-2004) in Interaction with Modernity and Urbanization" (University of Antwerp and Ghent University, 2005-2008, funded by the Flemish research 
foundation FWO) and "Antwerp Cinema City: A Media-Historical Investigation into Changes in Film Exhibition and Experiences of Cinemagoing in the City of Antwerp (I945-1995) with a Focus on the Rex Cinema Group" (University of Antwerp, 2009-2013, funded by the Antwerp University Research Council BOF). For details, see "Projects," Cinema City Cultures, accessed I8 March 20I8, http://www.cinemacitycultures.com/projects.html.

6. Unless indicated otherwise, the reconstruction is based on a variety of primary sources, including yearbooks (Jaarboek van de Belgische film and lists of exhibitors compiled by the Belgian Professional Chamber of Cinematography), trade journals (Ons Kinemadoek, Weekblad Cinema), coverage in local (editions of) newspapers (Gazet van Antwerpen, De Standaard, De Morgen, Het Nieuwsblad, De Nieuwe Gazet, Het Volk), in addition to sources from the private collections of Serge Bosschaerts and former Rex employee Paul Corluy, as well as dossiers related to Metropolis kept in Antwerp's city archive, FelixArchief, and in the archive of insolvency records of the Rex cinema group. The latter has been entrusted to the Visual and Digital Cultures Research Center ViDi, under supervision of Philippe Meers, at the University of Antwerp. All translations by the author.

7. See, for example, P. Hubbard, "Screen-Shifting: Consumption, 'Riskless Risks' and the Changing Geographies of Cinema," Environment and Planning A 34 (2002): I239; Hanson, From Silent Screen to Multi-Screen, I53. Other authors, however, also consider cinemas with two screens as multiplexes. See, for example, G. Edgerton, "The Multiplex. The Modern American Motion Picture Theater as Message," in Exhibition. The Film Reader, ed. I. Rae Hark (London \& New York: Routledge, 2002), I55-160, I55; Acland, Screen Traffic, I03.

8. E. Brunella, “Multiscreen, Multiplex, Megaplex?” European Cinema Journal 2 (I999): 2-3.

9. The first multiscreen complexes in both the US (I963) and the UK (I965) were so-called twins, constructed by splitting a single screen venue into two auditoriums. See, for example, Edgerton, "The Multiplex," I55, and Hanson, From Silent Screen to Multi-Screen, I2I for the US and the UK, respectively.

I0. Ibid., I36-I39; Edgerton, "The Multiplex," I58; T. Guback, "The Evolution of the Motion Picture Theater Business in the I980s," in Exhibition The Film Reader, ed. I. Rae Hark (London \& New York: Routledge, 2002), I27-I29.

II. W. Paul, "The K-Mart Audience at the Mall Movies," Film History 6 (I994): 489-492.

I2. Guback, "Evolution of the Motion Picture Theater Business," I33; K. J. Corbett, “The Big Picture: Theatrical Moviegoing, Digital Television and Beyond the Substitution Effect," Cinema Journal 40, no. 2 (200I): I7-34, 27-28. See also D. Docherty, D. E. Morrison and M. Tracey, "The British Film Industry and the Declining Audience: Demythologizing the Technological Threat," Journal of Communication, 36, 4 (I986): 27-39.

I3. Paul, "K-Mart Audience," 49I. See also J. Wasko, How Hollywood Works (London et al.: Sage, 2003), iı6ff.

I4. See, for example, Hanson, From Silent Screen to Multi-Screen, I2I-I22; Acland, Screen Traffic, 94; Gomery, Shared Pleasures, 105.

I5. Paul, "K-Mart Audience," 492; Hubbard, "Screen-Shifting," I240; Hanson, From Silent Screen to Multi-Screen, I28, I38-I38, I44, I62; Acland, Screen Traffic, 92.

I6. Ibid., I36-I39, I58-I59; Hubbard, "Screen-Shifting," I239. Based on their study of the relationship between travel time, distance and cinemagoing, Collins et al. found that when it comes to visits to the multiplex, travel time or distance were perceived in relative terms and 'cinemagoers may be willing to accept a longer journey in return for easier parking'. This finding, however, does not apply to non-multiplex cinemas. A. Collins, C. Hand and A. Ryder, "The Lure of the Multiplex? The Interplay of Time, Distance, and Cinema Attendance," Environment and Planning A 37 (2005): 483-501, 494.

I7. See Jancovich et al., Place of the Audience, 207-208 and Hanson, From Silent Screen to Multi-Screen, I62-165.

I8. Acland, Screen Traffic, Io8

I9. Ibid., I8, II3-II8. Emphasising the inconsistencies regarding the minimum number of screens, Acland concludes that the number of screens is not the most decisive criterion for defining the megaplex, rather the complex must encompass other forms of leisure activity.

20. Jancovich et al., Place of the Audience, 24I.

2I. N. Ravenscroft, "The Vitality and Viability of Town Centres," Urban Studies 37, no. I3 (2000): 2533-2549, 2533. For discussions of the cinemas' role in this, see Jancovich et al., Place of the Audience, 24I-243 and S. Hanson, “'Town Centres First': The Relocation of the Cinema from Out-of-Town to the Town Centre in Britain," in Cinema Beyond the City. Small-Town and Rural Film Culture in Europe, ed. Judith Thissen and Clemens Zimmermann (London: BFI-Palgrave, 20I6), 237-248, 239-240.

22. Hanson, "Town Centres First," 239-240; Jancovich et al., Place of the Audience, 24I-243.

23. Media business reporter Martin Peers quoted in Acland, Screen Traffic, I28.

24. Acland, Screen Traffic, I29.

25. Belgium was fifth (out of twenty countries) in line after the UK, Germany, Spain and France: Acland, Screen Traffic, 256. 
26. H. E. Browning and A. A. Sorrell, "Cinemas and Cinema-going in Great Britain," Journal of the Royal Statistical Society II7 (1952): I33-I65.

27. D. Biltereyst and P. Meers, ed. De Verlichte Stad. Een Geschiedenis van bioscopen, filmvertoningen en filmcultuur in Vlaanderen (Leuven: LannooCampus, 2007), 279 (Table I), 282 (Table 2). The year I945 witnessed the highest number of cinema tickets ever sold in Belgium. From that point onwards, the number of tickets sold would fall continuously for almost thirty years in a row.

28. See also European Audiovisual Observatory (EAO), The Film Industry in Belgium (I997), 25.

29. L. Van de Vijver, "The Cinema Is Dead, Long Live the Cinema!: Understanding the Social Experience of Cinemagoing Today," Participations. Journal of Audience \& Reception Studies I4, no. I (20I7): I29-44.

30. Acland, Screen Traffic, i36.

3I. Stad aan de Stroom (SaS), Onderzoek inplanting bioskoopkomplex (Antwerp, 30 April I99I).

32. Albert Bert in P. Duynslaegher, "Brussel kijkt naar Kinepolis," Knack I8, no. 39 (28 September I988): 49.

33. Duynslaegher, "Brussel kijkt naar Kinepolis".

34. Ibid.

35. D. Biltereyst and L. Van de Vijver. "Cinema in the 'Fog City': Film Exhibition and Sociography in Flanders," in Cinema Beyond the City. Small-Town a Rural Film Culture in Europe, ed. J. Thissen and C. Zimmermann (London: BFI-Palgrave, 20I6), 223-237, 232.

36. Vandenbosch, Report on Cinema Exploitation in Brussels, Agglomerations and Nationally (n.p., n.d.). How important modernisation was in revitalising the cinema sector since the I980s, was also claimed by the research team of MEDIA Salles, who linked the increase in admissions and occupancy rates to the opening of the many multiplexes by the Kinepolis group. Media Salles, The White Book of the European Exhibition Industry - Annex 2: Country Studies Belgium, 5 .

37. Kinepolis, accessed I November 20I7, https://corporate.kinepolis.com/.

38. G. Willems, "De bioscoopexploitatie tussen bloei en crisis (1945-1957)," in De Verlichte Stad. Een Geschiedenis van bioscopen, filmvertoningen en filmcultuur in Vlaanderen, ed. D. Biltereyst and P. Meers (Leuven: Lannoo, 2007), 8I-98, 83-84; as well as the graphs in Biltereyst and Meers, Verlichte Stad, 279, 280, 286. At that moment, Antwerp's population was approximately 250,000. Unless indicated otherwise, by Antwerp I mean the city of Antwerp (current postcodes 2000 to 2060), without taking into account its outlying districts (postcodes 2100 to 2600), which are currently also considered part of Antwerp.

39. L. Van de Vijver, "Gent Kinemastad. Een multimethodisch onderzoek naar de ontwikkeling van de filmexploitatie, filmprogrammering en filmbeleving in de stad Gent en randgemeenten (I896-20I0) als case binnen New Cinema History onderzoek" (PhD thesis, University of Ghent, 20II), 99.

40. In a survey of more than one thousand households in 1967 , watching television scored highest by far on Saturday and Sunday evenings (about forty percent), compared to cinemagoing (about one percent). M. Zwaenepoel, G. Cartrysse and L. Kempynck, Vrije tijd. Een sociologische analyse van het vrijetijdsgebruik en de vrijetijdsbehoeften van de Westvlaamse bevolking (Brugge: WES, I969); I42-I43, I46-I47. See also Frans Van Mechelen and Luc Delanghe, who described this 'bourgeoisification process due to increased wealth' in relation to cinemagoing and a change in mentality: 'Modern man does indeed want to spend a pleasant night out. He [sic] does not wish to spend his leisure time in a somewhat uncomfortable theatre, where he is most likely being dished up an offering he is able to watch on television every day in his cosy living room.' F. Van Mechelen and L. Delanghe, Vrijetijdsbesteding in Vlaanderen. Deel 3: Een onderzoek naar de weekendbesteding van de gezinnen in de winterperiode 1964-1965 (Antwerp: S.M. Ontwikkeling, I967), 61.

4I. F. Lauwers, De Keyserlei 125 Jaar (Antwerp: New Work Cy, I998), 4, 9.

42. The number and proximity of cinemas might have played an important role for the frequency of cinema attendances, as is suggested in the study by Van Mechelen and Delanghe about recreational activities in Flanders on weekends. Van Mechelen and Delanghe, Vrijetijdsbesteding in Vlaanderen, 6o, 63-64.

43. The only cinemas not belonging to Heylen's cinema empire in the Station Quarter were niche cinemas programming 'forbidden films' - that is, more sexually explicit material. For details of the first three decades of Heylen's career, see K. Lotze and P. Meers, “'They Don't Need Me in Heaven... There Are No Cinemas There, Ye Know' - Cinema Culture in Antwerp (Belgium) and the Empire of Georges Heylen, I945-75," in Watching Films: New Perspectives on Movie-Going, Exhibition and Reception, ed. K. Aveyard and A. Moran (Bristol, Chicago: Intellect, 2013), 223-44.

44. The case of the Rex cinema group has been intriguingly complex. Apart from the fact that the cinemas and companies involved in the exhibition and distribution of films were often only implicitly linked to Heylen 
(via addresses and shares, for example), the network of cinemas and involved companies proved to be especially tricky to disentangle, even by lawyers. Strictly speaking, Heylen's cinema group was not a concern, as the different companies that fell under Heylen's supervision could not technically be considered a 'business unit'.

45. While in the early I950s about a third of the cinemas in the inner city and adjacent neighbourhoods and districts had more than a thousand seats per cinema, by the early I990s their share had dropped to ten percent.

46. According to Heylen's general secretary, Jean Zeguers, in the I970s, Heylen's permanent architect, Rie Haan, introduced a plan to rebuild the block between De Keyserlei, Anneessensstraat and Van Etbornstraat, and to construct a ten-floor complex for cinemas, shops, offices and apartments. Heylen refused to participate because he would not be involved in many of the businesses there. Zeguers in W. Magiels, "Een kijkje achter de schermen. Een gesprek met Jean Zeguers, rechterhand van bioscooptycoon Georges Heylen,” in Magie van de cinema. Hollywood aan de Schelde, ed. W. Magiels and R. De Hert (Antwerp: Facet, 2004), 65-73, 72.

47. For more details about Meerburg, see, for example, P. Cuypers, "Filmdistributie en bioscoopwezen," in Aspecten van film en bioscoop, ed. G. Kruger (Amsterdam: Wetenschappelijke Uitgeverij I973), 95-I30, I20; K. Dibbets, "Bioscoopketens in Nederland. Ekonomiese koncentratie en geografiese spreiding van een bedrijfstak, I928-I977," (MA-thesis, University of Amsterdam, I980), 80.

48. Only for Turnhout, Leuven and Kortrijk was the quotient of the number of seats and number of cinemas higher. In I978, Antwerp was identified by economist Erik Faucompret as being among the top four Flemish cities (out of twelve) with the biggest theatres (in terms of seating capacity). E. Faucompret, "De Crisis in De Vlaamse Bioscoopindustrie," Economisch en Sociaal Tijdschrift 4 (I982): 457-468, 462.

49. With the conversion of Metro, Antwerp's last cinema giant was gone from the Station Quarter. However, with a seating capacity of, respectively, 450 and 650 seats, the two Metros still had a comparatively high number of seats: in I982, hardly any of the cinemas in the multiplexes or multiscreen theatres elsewhere in Belgium had more than 300 seats.

50. F. Van Laeken, “De kinepolisering van het bioskoopgebeuren,” De Morgen, I4 October I993: 22.

51. Duynslaegher, "Brussel kijkt naar Kinepolis," 5 I.

52. See Willems, "De bioscoopexploitatie tussen bloei en crisis," 9I; "De groei van de stad," Waar is de tijd 2I (I998): 5II, I. Bertels, T. Bisschops and B. Blondé, "Stadslandschap. Ontwikkelingen en verwikkelingen van een stedelijke ruimte," in Antwerpen. Biografie van een stad, ed. I. Bertels, B. De Munck and H. van Goethem (Antwerpen: Meulenhoff/Manteau, 20I0), II-66; R. Steyaert, G. Plomteux and A. Malliet, Architectuurgds van Antwerpen (Brepols, I993), XXII. According to social urban geographers Ilse Laureyssen and Myriam JansenVerbeke, the industry had already moved to Antwerp's suburbs in the I96os, followed by the services sector in the I980s. I. Laureyssen and M. Jansen-Verbeke, "De recente verschuiving in de vestigingsplaats van bioscopen in Antwerpen: oorzaken en gevolgen," De Aardrijkskunde I (I997): 45-50, 46.

53. Laureyssen and Jansen-Verbeke, "De recente verschuiving," 46. For memories of and opinions about the Station Quarter by its inhabitants and workers employed there, see, for example, Gazet van Antwerpen, ed. Antwerpen. Twintig wijken. Twintig werelden (Standaard, 2003): 229-242.

54. According to a report published by the EAO in I997, between I960 and I970, the number of screens in Belgium decreased by a half, and again by a half within the following two decades. In other words, between I960 and I992, the number of screens had fallen from I,506 to 314. The year I993 marked a radical turn, however. Mainly due to the opening of new giant multiplexes, the number of new screens 'more than made up for the closure of certain unprofitable cinema-theatres and screens'. EAO, Film Industry in Belgium, 22.

55. E. Faucompret, "De crisis in de Vlaamse bioscoopindustrie," 460, 464.

56. Other important exhibitors in Flanders and Brussels in I982 were, for instance, Claude Putzeys (six cinemas with a total of sixteen screens), Jos Rastelli (five cinemas, seven screens), René Mestdagh (four cinemas, fifteen screens) and Leon Senden (four cinemas, seven screens). Arnold Lummerzheim also belonged on this list (six cinemas, seven screens), but he went bankrupt that year (Van de Vijver, "Gent Kinemastad," I05).

57. Bert quoted in Duynslaegher, "Brussel kijkt naar Kinepolis," 49.

58. F. Claeys, F. Van Groenigen and G. D. Heylen, Overeenkomst, 4 April 1980.

59. This entertainment centre (to be named 'The Village') would be subdivided into three topics relating to three geographical levels. The first, named Schipperskwartier - corresponding to one of Antwerp's oldest and most traditional quarters - 'had to let people feel and discover Antwerp how it once was'. The second had as its topic the European Union ('eenwording'), offering Belgian beer and chocolate as well as accommodating, amongst other things, a Dutch mosselhuis (prawnhouse), a Danish tavern, a German Weinstube, an English pub, a Greek restaurant and an Italian pizzeria. The third theme was Hollywood and housed a 
copy of the store of Humphrey Bogart in the film Casablanca (director, year, country) and a copy of the famous Chinese theatre in Beverly Hills. A. Bert and J. Bert, "A. Bert and J. Bert to Stad Antwerpen, 23 August I989," Letter, n.p.

6o. Ibid.

6I. Acland, Screen Traffic, 92. Acland dedicates a whole chapter to the analogies between multiplexes and theme parks. Acland, Screen Traffic, I97-228.

62. Ibid., 92.

63. Ibid., I46.

64. Hanson, From Silent Screen to Multi-Screen, I28.

65. SaS, Report Onderzoek Metropolis (Antwerp, I6 April I99I).

66. SaS, Programma- en locatieonderzoek bioscoopcomplex (Antwerp, 4 June I99I), Io. As Van de Vijver shows, the coming of Decascoop in Ghent also caused most of the existing cinemas in the city to close down. Van de Vijver, "Gent Kinemastad," I04-I05.

67. SaS, Report Onderzoek Metropolis, 5.

68. Ibid., 9 .

69. See Collins et al. for an economic study of the influence of travel time on cinemagoing and the particular choice between multiplex and non-multiplexes: Collins et al., "Lure of the Multiplex".

70. SaS, Report Onderzoek Metropolis, 9.

7I. "Gevraagd: uw mening over Antwerpen Cinemastad," Gazet van Antwerpen, 9 April I992; P.S., "Cinema's toch liefst in de binnenstad. Matige belangstelling voor bioscoop-enquête," Gazet van Antwerpen, I5 April I992. The survey consisted of two questions: one about the general desirability of a new cinema complex in Antwerp, and the second about the preferred location (south Antwerp, north Antwerp or Linkeroever). Respondents had the choice to call or write.

72. Cools quoted in K.T., "Rex-wijnkelder helemaal uitverkocht," Gazet van Antwerpen, 29 June I993.

73. Besides Heylen's idea of a Rex cinema complex in the Station Quarter, two more parties had submitted plans at the beginning of 1993 for the construction of new cinema complexes in Antwerp's historical centre as well as in south Antwerp (DM 26 February I993: n.p.). One of the plans referred to the so-called Lombardia project: plans for the construction of four new cinemas at the heart of Antwerp's historical centre. These plans were proposed by the construction consortium Antwerpse Bouwwerken Verbeeck. The second plan was expressed by director and distributor Jan Verheyen. Neither project was ever realised. Regarding Verheyen's plans, see also Kloeck's critical reaction in, for example, P. Renard, "Het is allemaal film," Knack (27 January I993): 25.

74. G. Delveaux, "Metropolis," De Nieuwe Gazet, I October I993; P. Mijlemans, "De echt Antwaarpse cinema," De Morgen, I4 October I993. In order to make Metropolis 'of Antwerp', the cinema group conducted research on living and buying habits in Antwerp and planned to adjust the atmosphere of the cinema (with cosy niches) to the desires of Antwerp's citizens to combine a visit to the movies with a sociable night out.

75. Nolens quoted in Renard, "Het is allemaal film," 22.

76. A brochure including details about the multiplex is contained in the archive of insolvency records of the Rex cinema group. The brochure dates from April 1992 and was provided by architect Sylvia Denicelle in Nice, France.

77. Kloeck quoted in Renard, "Het is allemaal film," 23, 25. Since the I970s, Kloek had been an exhibitor of the less commercial cinemas Monty and Cartoon's in Antwerp's historical centre. He later took over the Calypso triplex across from Heylen's flagship cinema, Rex, and also three of Heylen's screens located on De Keyserlei, across from Central Station.

78. Heylen quoted in W. Magiels and R. D. Hert, ed., Magie van de Cinema. Hollywood aan de Schelde (Antwerp: Facet, 2004), 75 .

79. J. Theunis, Conclusie. Rechtbank van Koophandel te Antwerpen, A.R. nr. 09925/93 (December I993), I0.

80. Laureyssen and Jansen-Verbeke "De recente verschuiving," 47-48.

8I. Although Heylen's claim was considered unfounded for a variety of reasons, NV Metropolis' decision was based on the consideration that a lawsuit would do no good to the image of the young company, and the financial burdens and energy invested in it would stand in the way of setting up their new business in a timely manner. Details of the course of events and arguments are treated in the author's forthcoming dissertation relating to the PhD project "Antwerp Cinema City" mentioned in the introduction. 
82. See, for example, Delveaux, “Metropolis," V. Janssens, "Calypso moet cinema-tij keren. Eigenaar van Cartoon's Eric Kloeck koopt zalencomplex over van Super Club," Het Nieuwsblad, 26 March I992; P. Mijlemans, "Platonische liefde tussen Antwerpse bioskopen," De Morgen, I4 October I993.

83. Laureyssen and Jansen-Verbeke, "De recente verschuiving," 48. Collins et al. came to a similar conclusion in their study of the impact of travel time on cinemagoing. Their results suggested that multiplex visitors were willing to travel longer distances if easy parking was guaranteed. Collins et al., "Lure of the Multiplex," 496.

84. Laureyssen and Jansen-Verbeke, "De recente verschuiving," 48.

85. Heylen quoted in G. Delveaux, "Rex bouwt filmcomplex," De Nieuwe Gazet, 5 January I993.

86. Heylen quoted in F. Crols, "De Grote Draak van Cinétown," Trends. Financieel Ekonomisch Magazine II, 239 (1985): 49 .

87. Laureyssen and Jansen-Verbeke, "De recente verschuiving," 49.

88. M.-A. Wilssens, "Legendarische De Keyserlei in stervensnood,” De Standaard, 7 February I994.

89. Kloeck quoted in P. Mijlemans, "Biotoop stadsbioscoop bedreigd," De Morgen, I4 October I993.

90. Laureyssen and Jansen-Verbeke, "De recente verschuiving," 46.

9I. Immobiliën Hugo Ceusters, Rapportering Rex Dossier, November I994: 3, II.

92. See the letter from Kredietbank to the Rex's receiver, Van Passel, dated 23 May I995. A copy of the letter is kept as part of the archive of insolvency records, box 7 .

93. The multiplex is now exploited by the French theatre, distribution and production chain Union Générale Cinématographique (UGC).

\section{Biography}

Kathleen Lotze has been involved in media-related research projects at different universities in Germany, Belgium and the Netherlands since I999, including Cinema Context (University of Amsterdam), Enlightened City (University of Antwerp) and CREATE: Creative Amsterdam - An E-Humanities Perspective (University of Amsterdam). For her PhD project, Antwerp Cinema City, she focuses on changes in film exhibition and experiences of cinemagoing in Antwerp between I945 and I995. Results of her work have been presented at international conferences and have been published in several peer-reviewed journals and books. Currently, she works for the CLARIAH-project MIMEHIST (University of Amsterdam) and for the international comparative research project European Cinema Audiences (Oxford Brookes University). 